\title{
THE SYNTHESIS AND STUDY OF TETRANUCLEAR CLUSTER $\left[\mathrm{Fe}_{4} \mathrm{O}_{2}\left(\mathrm{CCl}_{3} \mathrm{COO}\right)_{8}(\mathrm{THF})_{2}(\mathrm{DMF})\left(\mathrm{H}_{2} \mathrm{O}\right)\right] \cdot \mathrm{THF}$
}

\author{
Denis Prodius $^{\mathrm{a}}$, Valeriu Mereacre ${ }^{\mathrm{a}}$, Sergiu Shova ${ }^{\mathrm{b}}$, Maria Gdaniec $^{\mathrm{c}}$, Yurii Simonov, \\ Lorenzo Sorace $^{\mathrm{e}}$, Andrea Caneschi ${ }^{\mathrm{e}}$, Nicolae Stanica ${ }^{\mathrm{f}}$, Ion Geru ${ }^{\mathrm{g}}$, Constantin Turta*a \\ ${ }^{a}$ Institute of Chemistry of the Academy of Sciences of Moldova, MD-2028 Chisinau, Moldova \\ ${ }^{b}$ State University of Moldova, MD-2009 Chisinau, Moldova \\ ${ }^{c}$ Faculty of Chemistry, A. Mickiewicz University, Grunwaldzka 6, 60-780, Poznań, Poland \\ ${ }^{d}$ Institute of Applied Physics of the Academy of Sciences of Moldova, MD-2028 Chisinau, Moldova \\ ${ }^{e}$ Department of Chemistry and INSTM Research Unit, University of Florence, Florence, Italy \\ Institute of Physical Chemistry "Murgulescu”, Romanian Academy, Bucharest, Romania \\ ${ }^{g}$ The Metrology and Material Analysis Centre, Academy of Sciences of Moldova, Chisinau, Moldova \\ *Corresponding author: Fax:(37322) 739954; Tel:(37322) 739755; E-mail: turtalcba@yahoo.com; cturta@cc.acad.md
}

\begin{abstract}
The novel bis $\left(\mu_{3}\right.$-oxo $)$ tetranuclear trichloracetate cluster, $\left[\mathrm{Fe}_{4} \mathrm{O}_{2}\left(\mathrm{CCl}_{3} \mathrm{COO}\right)_{8}(\mathrm{THF})_{2}(\mathrm{DMF})\left(\mathrm{H}_{2} \mathrm{O}\right)\right] \cdot \mathrm{THF}(\mathbf{1})$, has been synthesised and subsequently characterised by X-ray structure analysis, magnetic measurements and infra red

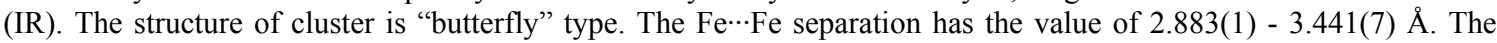
coordination number of iron (III) is 6. Magnetic studies reveal the presence of an antiferromagnetic exchange in the parallelogram skeletons of the tetranuclear species. Using the spin Hamiltonian $\mathrm{H}=-2 J_{w b}\left(\hat{\mathrm{S}}_{1} \hat{\mathrm{S}}_{2}+\hat{\mathrm{S}}_{2} \hat{\mathrm{S}}_{3}+\hat{\mathrm{S}}_{3} \hat{\mathrm{S}}_{4}+\hat{\mathrm{S}}_{4} \hat{\mathrm{S}}_{1}\right)-$ $2 J_{b b} \hat{\mathrm{S}}_{2} \hat{\mathrm{S}}_{4 \mathrm{v}}+\mathrm{g} \mu_{\beta}\left(\hat{\mathrm{S}}_{1 \mathrm{z}}+\hat{\mathrm{S}}_{2 \mathrm{z}}+\hat{\mathrm{S}}_{3 \mathrm{z}}+\hat{\mathrm{S}}_{4 \mathrm{z}}\right) \mathrm{B}$, the fitting parameters $J_{b b}=-14.3 \mathrm{~cm}^{-1}, J_{w b}=-32.1 \mathrm{~cm}^{-1}, \mathrm{~g}=2.07, \rho_{\text {param }}$ impur. $=4.2 \%, \Theta_{\text {Curie-Weiss const. }}=-0.5 \mathrm{~K}$ and $\mathrm{R}=6.8 \cdot 10^{-5}$ were obtained.
\end{abstract}

Keywords: $\left\{\mathrm{Fe}_{4} \mathrm{O}_{2}\right\}$ core; Homotetranuclear carboxylate; Crystal structure; Antiferromagnetic exchange.

\section{Introduction}

For a long time the permanent interest of the investigators to oxo- carboxylate complexes of transition metals was due to their usefulness in resolving the problems of theory of magnetism of coordination compounds [1-5] and practical problems connected with the specific catalysis [6] and biological active substances [7].

In the last few years this class of substances has become the focus of much attention by the development of the new scientific direction concerning the best way to obtain single molecule magnet (SMM) [8-10]. At the same time the oxo iron carboxylate complexes are good model compounds for the active centers of a number of metalloproteins such as: hemerythrin ( $\mathrm{Hr})[11,12]$, ribonucleotide reductase (RR) [11, 12], purple acid phosphatases (PAPs) [11-14]; ferreascidin (Fasc) [15, 16], and ferritin (Fn) $[17,18]$. Hr, RR, PAPs contain dinuclear iron sites, Fasc - supposedly three nuclear sites, and Fn - a large polynuclear iron oxide core. After the first publication of the synthesis and study the tetranuclear iron(III) trifluoroacetate [19-21] the large number of complexes of this series was synthesized and investigated by different methods [22-26].

In attempt to continue the previous studying and obtaining the model of the active centers of polyiron enzymes we report herein the synthesis of tetranuclear iron(III) complex with trichloracetic acid.

\section{Results and discussion}

Up to date various polynuclear complexes with chloro containing acetic acids have been synthesized and structurally characterized [27-31]. Most of these complexes were synthesized through step concerning treatment of basic acetates of $\mathrm{d}$ - elements with corresponding acids in aqueous solutions. It is worth mentioning that complex $\mathbf{1}$ was prepared by the procedure concerning the extract of the barium ion in heterotrinuclear complex by sulphate anion in "water-THF-toluene" mixture.

\subsection{Structure}

The crystal 1 has a molecular structure build from neutral tetranuclear $\left[\mathrm{Fe}_{4} \mathrm{O}_{2}\left(\mathrm{CCl}_{3} \mathrm{COO}\right)_{8}(\mathrm{THF})_{2}(\mathrm{DMF})\left(\mathrm{H}_{2} \mathrm{O}\right)\right]$ complexes and THF solvate molecules in 1:1 ratio. The X-ray study revealed that tetranuclear entity could be described as a typical "butterfly" type structure, as depicted in figure 1 . The four metal atoms are linked through two $\mu_{3}$-oxo centers and six bidentate-bridged carboxylate ligands coordinated in syn-syn fashion. Other two carboxylate anions behave as monodentate ligands being coordinated to $\mathrm{Fe}(3)$ and $\mathrm{Fe}(4)$ atoms. The $\mathrm{Fe} \cdots \mathrm{Fe}$ separation within the $\mathrm{Fe}_{4}\left(\mu_{3^{-}}\right.$ $\mathrm{O})_{2}$ core exhibit the following values: $\mathrm{Fe}(1)-\mathrm{Fe}(4)$ 3.441(7); $\mathrm{Fe}(1)-\mathrm{Fe}(3)$ 3.372(6); $\mathrm{Fe}(1)-\mathrm{Fe}(2)$ 2.883(5); $\mathrm{Fe}(2)-\mathrm{Fe}(4)$ 3.373(7); $\mathrm{Fe}(2)-\mathrm{Fe}(3)$ 3.437(6) $\AA$ (Tabl.2). In contrast to $\mathrm{Fe}(3)$ and $\mathrm{Fe}(4), \mathrm{Fe}(1)$ and $\mathrm{Fe}(2)$ atoms coordinate as a monodentate ligand one DMF molecule $(\mathrm{Fe}(1)-\mathrm{O}(19)=2.03(2) \AA)$ and one water molecule $(\mathrm{Fe}(2)-\mathrm{O}(1 \mathrm{w})=2.02(2) \AA)$, respectively. The coordinated water molecule $\mathrm{O}(1 \mathrm{w})$ forms two H-bonds, one with the oxygen atoms of solvate THF and another with the monodentate carboxylate ligands with the distances $\mathrm{O}(1 \mathrm{w}) \cdots \mathrm{O}(18) 2.81(4), \mathrm{O}(1 \mathrm{w}) \mathrm{H} \cdots \mathrm{O}(18) 1.97$, $\mathrm{O}(1 \mathrm{w}) \cdots \mathrm{O}(22)$ 2.74(3), $\mathrm{O}(1 \mathrm{w}) \mathrm{H}^{\cdots} \mathrm{O}(18) 1.99(\AA)$ and angles $\mathrm{O}(1 \mathrm{w}) \mathrm{HO}(18)$ 155.1, $\mathrm{O}(1 \mathrm{w}) \mathrm{HO}(22) 140.2\left(^{\circ}\right)$. The $\mathrm{Fe}_{4}\left(\mu_{3^{-}}\right.$ $\mathrm{O})_{2}$ core is essentially non-planar. The dihedral angle between two $\mathrm{Fe}_{3}\left(\mu_{3}-\mathrm{O}\right)$ fragments is equal to $33.0(1)^{\circ}$. The deviation of $\mu_{3}$-oxigen atoms from the respective plane is different: $0.35(1) \AA$ for $\mathrm{O}(1)$ and $0.24(2) \AA$ for $\mathrm{O}(2)$. Each iron ions has an $\mathrm{O}_{6}$ slightly distorted octahedron coordination, but their environment is different. In particular, the 
coordination site of the $\mathrm{Fe}(3)$ and $\mathrm{Fe}(4)$, which comprises only one $\mu_{3}$-O bridging atom, are similar and differ from that for $\mathrm{Fe}(1)$ and $\mathrm{Fe}(2)$ atoms, which include only two $\mu_{3}-\mathrm{O}$ bridging atoms (Fig. 1).

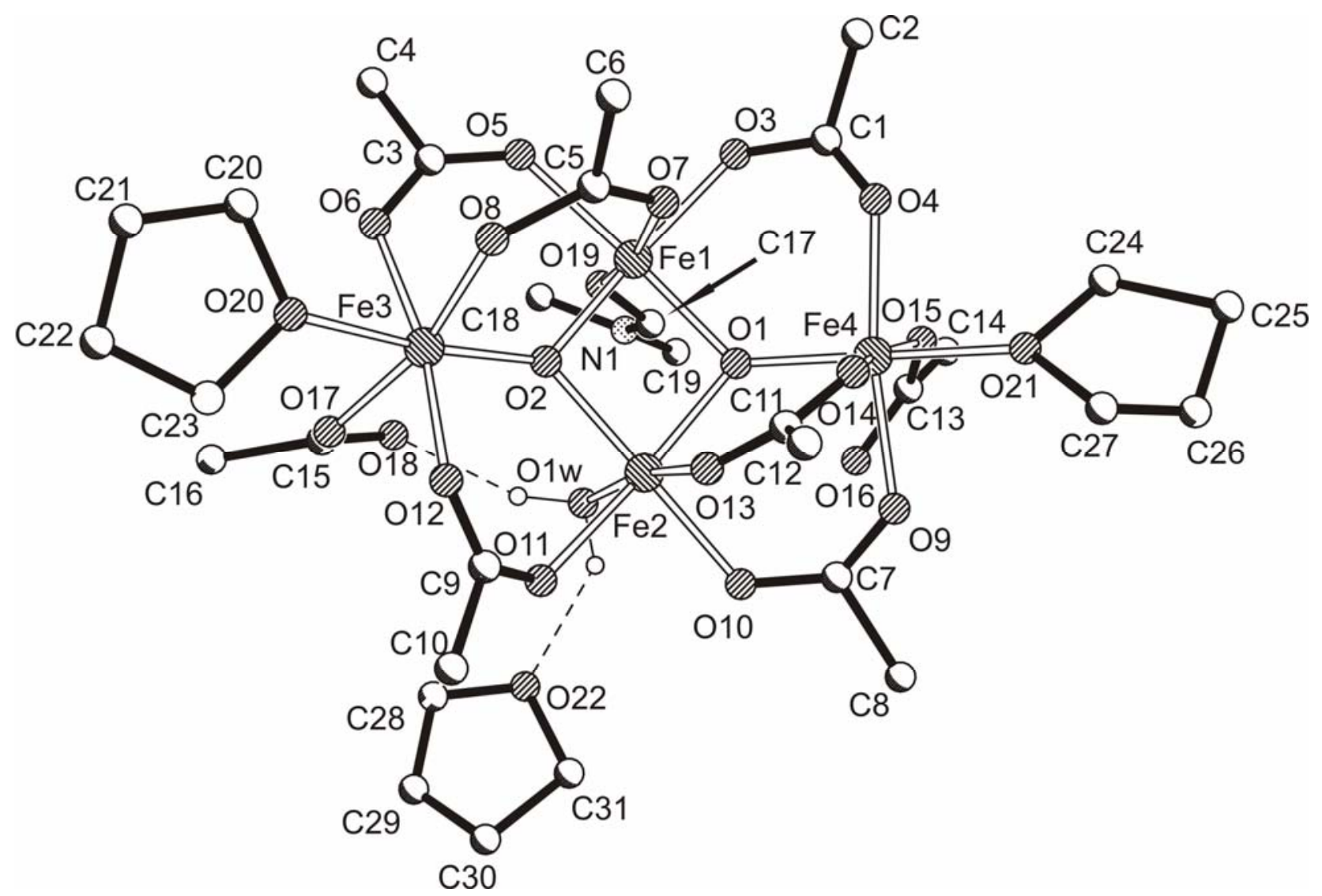

Figure 1. View of the unsymmetrical unit in crystal structure of $\left[\mathrm{Fe}_{4} \mathrm{O}_{2}\left(\mathrm{CCl}_{3} \mathrm{COO}\right)_{8}(\mathrm{THF})_{2}(\mathrm{DMF})\left(\mathrm{H}_{2} \mathrm{O}\right)\right] \cdot \mathrm{THF}$ (1). The chloride atoms and the $\mathrm{H}$ atoms bonded to carbon are omitted for clarity.

At the same time, the coordination site of the last pair is also different as the coordination of $\mathrm{Fe}(1)$ atoms is completed by DMF molecule $(\mathrm{Fe}(1)-\mathrm{O}(19)=2.03(2) \AA)$, while the coordination of $\mathrm{Fe}(2)$ - by one water molecule $(\mathrm{Fe}(2)-\mathrm{O}(1 \mathrm{w})=2.02(2) \AA)$.

Table 1. Selected bond lengths $(\AA)$ and angles $(\mathrm{deg})$ for $\left[\mathrm{Fe}_{4} \mathrm{O}_{2}\left(\mathrm{CCl}_{3} \mathrm{COO}\right)_{8}(\mathrm{THF})_{2}(\mathrm{DMF})\left(\mathrm{H}_{2} \mathrm{O}\right)\right] \cdot \mathrm{THF}$.

\begin{tabular}{|llll|}
\hline $\mathrm{O}(1)-\mathrm{Fe}(1)$ & $1.942(18)$ & $\mathrm{O}(1)-\mathrm{Fe}(2)$ & $1.978(17)$ \\
\hline $\mathrm{O}(2)-\mathrm{Fe}(3)$ & $1.85(2)$ & $\mathrm{O}(2)-\mathrm{Fe}(1)$ & $1.882(18)$ \\
\hline $\mathrm{O}(2)-\mathrm{Fe}(2)$ & $1.946(19)$ & $\mathrm{O}(1 \mathrm{~W})-\mathrm{Fe}(2)$ & $2.01(2)$ \\
\hline $\mathrm{O}(3)-\mathrm{Fe}(1)$ & $1.954(18)$ & $\mathrm{O}(4)-\mathrm{Fe}(4)$ & $2.05(2)$ \\
\hline $\mathrm{O}(5)-\mathrm{Fe}(1)$ & $2.02(2)$ & $\mathrm{O}(1)-\mathrm{Fe}(4)$ & $1.85(2)$ \\
\hline $\mathrm{O}(7)-\mathrm{Fe}(1)$ & $2.05(2)$ & $\mathrm{O}(6)-\mathrm{Fe}(3)$ & $2.074(16)$ \\
\hline $\mathrm{O}(9)-\mathrm{Fe}(4)$ & $2.04(2)$ & $\mathrm{O}(8)-\mathrm{Fe}(3)$ & $2.03(2)$ \\
\hline $\mathrm{O}(11)-\mathrm{Fe}(2)$ & $2.09(2)$ & $\mathrm{O}(10)-\mathrm{Fe}(2)$ & $2.073(15)$ \\
\hline $\mathrm{O}(13)-\mathrm{Fe}(2)$ & $2.084(19)$ & $\mathrm{O}(12)-\mathrm{Fe}(3)$ & $2.051(19)$ \\
\hline $\mathrm{O}(15)-\mathrm{Fe}(4)$ & $1.946(18)$ & $\mathrm{O}(14)-\mathrm{Fe}(4)$ & $2.00(2)$ \\
\hline $\mathrm{O}(19)-\mathrm{Fe}(1)$ & $2.03(2)$ & $\mathrm{O}(17)-\mathrm{Fe}(3)$ & $2.091(18)$ \\
\hline $\mathrm{O}(21)-\mathrm{Fe}(4)$ & $2.09(3)$ & $\mathrm{O}(20)-\mathrm{Fe}(3)$ & $1.298(19)$ \\
\hline $\mathrm{C}(1)-\mathrm{O}(4)$ & $1.295(19)$ & $\mathrm{C}(1)-\mathrm{O}(3)$ & $1.14(4)$ \\
\hline $\mathrm{C}(1)-\mathrm{C}(2)$ & $1.54(4)$ & $\mathrm{C}(3)-\mathrm{O}(5)$ & $1.53(5)$ \\
\hline $\mathrm{C}(3)-\mathrm{O}(6)$ & $1.42(3)$ & $\mathrm{C}(3)-\mathrm{C}(4)$ & $1.41(2)$ \\
\hline $\mathrm{C}(5)-\mathrm{O}(7)$ & $1.40(2)$ & $\mathrm{C}(5)-\mathrm{O}(8)$ & $1.25(2)$ \\
\hline $\mathrm{C}(5)-\mathrm{C}(6)$ & $1.34(4)$ & $\mathrm{C}(7)-\mathrm{O}(9)$ & $1.64(4)$ \\
\hline $\mathrm{C}(7)-\mathrm{O}(10)$ & $1.25(2)$ & $\mathrm{C}(7)-\mathrm{C}(8)$ & $1.257(16)$ \\
\hline $\mathrm{C}(9)-\mathrm{O}(11)$ & $1.257(16)$ & $\mathrm{C}(9)-\mathrm{O}(12)$ & $1.53(3)$ \\
\hline $\mathrm{C}(11)-\mathrm{O}(14)$ & $1.209(18)$ & $\mathrm{C}(9)-\mathrm{C}(10)$ & \\
\hline
\end{tabular}




\begin{tabular}{|llll|}
\hline $\mathrm{C}(11)-\mathrm{C}(12)$ & $1.56(4)$ & $\mathrm{C}(11)-\mathrm{O}(13)$ & $1.209(18)$ \\
\hline $\mathrm{C}(13)-\mathrm{O}(16)$ & $1.28(5)$ & $\mathrm{C}(13)-\mathrm{O}(15)$ & $1.20(4)$ \\
\hline $\mathrm{C}(15)-\mathrm{O}(17)$ & $1.27(4)$ & $\mathrm{C}(13)-\mathrm{C}(14)$ & $1.53(4)$ \\
\hline $\mathrm{C}(15)-\mathrm{C}(16)$ & $1.64(6)$ & $\mathrm{C}(15)-\mathrm{O}(18)$ & $1.32(4)$ \\
\hline $\mathrm{C}(17)-\mathrm{N}(1)$ & $1.366(19)$ & $\mathrm{C}(17)-\mathrm{O}(19)$ & $1.25(4)$ \\
\hline $\mathrm{C}(18)-\mathrm{N}(1)$ & $1.38(6)$ & $\mathrm{C}(19)-\mathrm{N}(1)$ & $1.42(4)$ \\
\hline $\mathrm{C}(20)-\mathrm{O}(20)$ & $1.45(2)$ & $\mathrm{C}(20)-\mathrm{C}(21)$ & $1.48(2)$ \\
\hline $\mathrm{C}(21)-\mathrm{C}(22)$ & $1.48(2)$ & $\mathrm{C}(22)-\mathrm{C}(23)$ & $1.48(2)$ \\
\hline $\mathrm{C}(23)-\mathrm{O}(20)$ & $1.45(2)$ & $\mathrm{C}(24)-\mathrm{O}(21)$ & $1.45(2)$ \\
\hline $\mathrm{C}(24)-\mathrm{C}(25)$ & $1.48(2)$ & $\mathrm{C}(25)-\mathrm{C}(26)$ & $1.48(2)$ \\
\hline $\mathrm{C}(26)-\mathrm{C}(27)$ & $1.48(2)$ & $\mathrm{C}(27)-\mathrm{O}(21)$ & $1.45(2)$ \\
\hline $\mathrm{C}(28)-\mathrm{O}(22)$ & $1.45(2)$ & $\mathrm{C}(28)-\mathrm{C}(29)$ & $1.47(2)$ \\
\hline $\mathrm{C}(29)-\mathrm{C}(30)$ & $1.48(2)$ & $\mathrm{C}(30)-\mathrm{C}(31)$ & $1.48(2)$ \\
\hline $\mathrm{C}(31)-\mathrm{O}(22)$ & $1.45(2)$ & & \\
\hline
\end{tabular}

\begin{tabular}{|c|c|c|c|}
\hline $\mathrm{O}(2)-\mathrm{Fe}(1)-\mathrm{O}(1)$ & $84.7(8)$ & $\mathrm{O}(2)-\mathrm{Fe}(1)-\mathrm{O}(19)$ & 96.4(9) \\
\hline $\mathrm{O}(1)-\mathrm{Fe}(1)-\mathrm{O}(19)$ & 94.3(8) & $\mathrm{O}(2)-\mathrm{Fe}(1)-\mathrm{O}(3)$ & 174.1(9) \\
\hline $\mathrm{O}(1)-\mathrm{Fe}(1)-\mathrm{O}(3)$ & $95.0(9)$ & $\mathrm{O}(19)-\mathrm{Fe}(1)-\mathrm{O}(3)$ & $89.5(8)$ \\
\hline $\mathrm{O}(2)-\mathrm{Fe}(1)-\mathrm{O}(5)$ & $95.2(9)$ & $\mathrm{O}(1)-\mathrm{Fe}(1)-\mathrm{O}(5)$ & $177.9(8)$ \\
\hline $\mathrm{O}(19)-\mathrm{Fe}(1)-\mathrm{O}(5)$ & $83.7(9)$ & $\mathrm{O}(3)-\mathrm{Fe}(1)-\mathrm{O}(5)$ & $85.2(9)$ \\
\hline $\mathrm{O}(2)-\mathrm{Fe}(1)-\mathrm{O}(7)$ & $90.3(8)$ & $\mathrm{O}(1)-\mathrm{Fe}(1)-\mathrm{O}(7)$ & $94.5(7)$ \\
\hline $\mathrm{O}(19)-\mathrm{Fe}(1)-\mathrm{O}(7)$ & 169.4(7) & $\mathrm{O}(3)-\mathrm{Fe}(1)-\mathrm{O}(7)$ & $83.8(8)$ \\
\hline $\mathrm{O}(5)-\mathrm{Fe}(1)-\mathrm{O}(7)$ & $87.6(8)$ & $\mathrm{O}(2)-\mathrm{Fe}(1)-\mathrm{Fe}(2)$ & $41.9(6)$ \\
\hline $\mathrm{O}(1)-\mathrm{Fe}(1)-\mathrm{Fe}(2)$ & $43.1(5)$ & $\mathrm{O}(19)-\mathrm{Fe}(1)-\mathrm{Fe}(2)$ & $93.7(5)$ \\
\hline $\mathrm{O}(3)-\mathrm{Fe}(1)-\mathrm{Fe}(2)$ & $138.0(7)$ & $\mathrm{O}(5)-\mathrm{Fe}(1)-\mathrm{Fe}(2)$ & $136.7(7)$ \\
\hline $\mathrm{O}(7)-\mathrm{Fe}(1)-\mathrm{Fe}(2)$ & $96.8(5)$ & $\mathrm{O}(2)-\mathrm{Fe}(2)-\mathrm{O}(1)$ & $82.2(8)$ \\
\hline $\mathrm{O}(2)-\mathrm{Fe}(2)-\mathrm{O}(1 \mathrm{~W})$ & $88.2(9)$ & $\mathrm{O}(1)-\mathrm{Fe}(2)-\mathrm{O}(1 \mathrm{~W})$ & 101.1(7) \\
\hline $\mathrm{O}(2)-\mathrm{Fe}(2)-\mathrm{O}(10)$ & $170.4(8)$ & $\mathrm{O}(1)-\mathrm{Fe}(2)-\mathrm{O}(10)$ & $94.8(8)$ \\
\hline $\mathrm{O}(1 \mathrm{~W})-\mathrm{Fe}(2)-\mathrm{O}(10)$ & $83.3(9)$ & $\mathrm{O}(2)-\mathrm{Fe}(2)-\mathrm{O}(13)$ & $98.5(8)$ \\
\hline $\mathrm{O}(1)-\mathrm{Fe}(2)-\mathrm{O}(13)$ & $88.1(7)$ & $\mathrm{O}(1 \mathrm{~W})-\mathrm{Fe}(2)-\mathrm{O}(13)$ & $169.3(7)$ \\
\hline $\mathrm{O}(10)-\mathrm{Fe}(2)-\mathrm{O}(13)$ & $90.5(8)$ & $\mathrm{O}(2)-\mathrm{Fe}(2)-\mathrm{O}(11)$ & $93.1(8)$ \\
\hline $\mathrm{O}(1)-\mathrm{Fe}(2)-\mathrm{O}(11)$ & $169.3(8)$ & $\mathrm{O}(1 \mathrm{~W})-\mathrm{Fe}(2)-\mathrm{O}(11)$ & $88.3(8)$ \\
\hline $\mathrm{O}(10)-\mathrm{Fe}(2)-\mathrm{O}(11)$ & $91.3(8)$ & $\mathrm{O}(13)-\mathrm{Fe}(2)-\mathrm{O}(11)$ & $83.1(8)$ \\
\hline $\mathrm{O}(2)-\mathrm{Fe}(2)-\mathrm{Fe}(1)$ & $40.3(6)$ & $\mathrm{O}(1)-\mathrm{Fe}(2)-\mathrm{Fe}(1)$ & $42.1(5)$ \\
\hline $\mathrm{O}(1 \mathrm{~W})-\mathrm{Fe}(2)-\mathrm{Fe}(1)$ & $92.7(5)$ & $\mathrm{O}(13)-\mathrm{Fe}(2)-\mathrm{Fe}(1)$ & $97.9(4)$ \\
\hline $\mathrm{O}(10)-\mathrm{Fe}(2)-\mathrm{Fe}(1)$ & $135.3(6)$ & $\mathrm{O}(11)-\mathrm{Fe}(2)-\mathrm{Fe}(1))$ & $133.2(6$ \\
\hline $\mathrm{O}(2)-\mathrm{Fe}(3)-\mathrm{O}(17)$ & 101.4(9) & $\mathrm{O}(2)-\mathrm{Fe}(3)-\mathrm{O}(8)$ & $90.1(9)$ \\
\hline $\mathrm{O}(17)-\mathrm{Fe}(3)-\mathrm{O}(8)$ & $167.0(9)$ & $\mathrm{O}(2)-\mathrm{Fe}(3)-\mathrm{O}(6)$ & $94.4(7)$ \\
\hline $\mathrm{O}(17)-\mathrm{Fe}(3)-\mathrm{O}(6)$ & $85.4(7)$ & $\mathrm{O}(8)-\mathrm{Fe}(3)-\mathrm{O}(6)$ & $87.7(7)$ \\
\hline $\mathrm{O}(2)-\mathrm{Fe}(3)-\mathrm{O}(12)$ & $97.0(7)$ & $\mathrm{O}(17)-\mathrm{Fe}(3)-\mathrm{O}(12)$ & $89.4(7)$ \\
\hline $\mathrm{O}(8)-\mathrm{Fe}(3)-\mathrm{O}(12)$ & $95.3(7)$ & $\mathrm{O}(6)-\mathrm{Fe}(3)-\mathrm{O}(12)$ & $168.2(8)$ \\
\hline $\mathrm{O}(2)-\mathrm{Fe}(3)-\mathrm{O}(20)$ & 171.3(9) & $\mathrm{O}(17)-\mathrm{Fe}(3)-\mathrm{O}(20)$ & $87.3(8)$ \\
\hline $\mathrm{O}(8)-\mathrm{Fe}(3)-\mathrm{O}(20)$ & $81.2(8)$ & $\mathrm{O}(6)-\mathrm{Fe}(3)-\mathrm{O}(20)$ & $85.2(7)$ \\
\hline $\mathrm{O}(12)-\mathrm{Fe}(3)-\mathrm{O}(20)$ & $84.0(7)$ & $\mathrm{O}(1)-\mathrm{Fe}(4)-\mathrm{O}(15)$ & $99.4(9)$ \\
\hline $\mathrm{O}(1)-\mathrm{Fe}(4)-\mathrm{O}(9)$ & $95.3(9)$ & $\mathrm{O}(15)-\mathrm{Fe}(4)-\mathrm{O}(9)$ & $91.7(9)$ \\
\hline $\mathrm{O}(1)-\mathrm{Fe}(4)-\mathrm{O}(4)$ & $94.5(9)$ & $\mathrm{O}(15)-\mathrm{Fe}(4)-\mathrm{O}(4)$ & $88.3(9)$ \\
\hline $\mathrm{O}(9)-\mathrm{Fe}(4)-\mathrm{O}(4)$ & $170.1(11)$ & $\mathrm{O}(1)-\mathrm{Fe}(4)-\mathrm{O}(14)$ & $93.5(9)$ \\
\hline $\mathrm{O}(15)-\mathrm{Fe}(4)-\mathrm{O}(14)$ & $167.1(12)$ & $\mathrm{O}(9)-\mathrm{Fe}(4)-\mathrm{O}(14)$ & $86.8(8)$ \\
\hline $\mathrm{O}(4)-\mathrm{Fe}(4)-\mathrm{O}(14)$ & $91.1(8)$ & $\mathrm{O}(1)-\mathrm{Fe}(4)-\mathrm{O}(21)$ & $175.6(8)$ \\
\hline $\mathrm{O}(15)-\mathrm{Fe}(4)-\mathrm{O}(21)$ & $85.0(10)$ & $\mathrm{O}(9)-\mathrm{Fe}(4)-\mathrm{O}(21)$ & $85.0(10)$ \\
\hline $\mathrm{O}(4)-\mathrm{Fe}(4)-\mathrm{O}(21)$ & $85.1(9)$ & $\mathrm{O}(14)-\mathrm{Fe}(4)-\mathrm{O}(21)$ & $82.1(10)$ \\
\hline
\end{tabular}

\subsection{Infrared spectra}

The solid state IR spectra of $\mathbf{1}$ indicate the presence of carboxylate, THF, $\mathrm{H}_{2} \mathrm{O}$ and $\left\{\mathrm{Fe}_{4} \mathrm{O}_{2}\right\}$ groups. The characteristic vibration frequencies for THF groups appear at $\sim 3450-3600$ and $2800-3000 \mathrm{~cm}^{-1}$. At the same time it is possible to appreciate the presence of a double pair of carboxylate stretching vibrations $v_{\text {as }}(\mathrm{COO})$ and $v_{\mathrm{s}}(\mathrm{COO})$ at 1645 and $1670 \mathrm{~cm}^{-1}$, and $1380 \mathrm{~cm}^{-1}$ respectively i.e. two types of carboxylate group in their crystal structures are present which is in according with X-ray data. These bands are shifted to lower energy by $45-75 \mathrm{~cm}^{-1}$ relative to the trinuclear basic acetates [32] due to the replacement of the $\mathrm{CH}_{3}$ radical by the much more powerfully electron-accepting $\mathrm{CCl}_{3}$ 
moieties which weaken the $\mathrm{M}-\mathrm{O}_{\text {carb }}$ force constant. The $\mathrm{v}_{\text {as }}(\mathrm{C}-\mathrm{Cl})\left(\mathrm{A}^{\prime \prime}, \mathrm{A}^{\prime}\right)$ vibration frequencies for $\mathrm{CCl}_{3}$ groups are present at $832(\mathrm{~s})$ and $826(\mathrm{~s}) \mathrm{cm}^{-1}[33]$.

\subsection{Magnetic properties}

The magnetic properties of compound 1 have been measured in the $300-1.8 \mathrm{~K}$ range of temperature. At 300 $\mathrm{K}$ the value of $\chi_{\mathrm{M}} \cdot \mathrm{T}$ is $3.91 \mathrm{~cm}^{3} \cdot \mathrm{K} \cdot \mathrm{mol}^{-1}$. Lowering the temperature this value is diminished gradually and at $1.8 \mathrm{~K}$ is equal $0.10 \mathrm{~cm}^{3} \cdot \mathrm{K} \cdot \mathrm{mol}^{-1}$ thus indicating on antiferromagnetic interaction between ions of iron (III). In order to describe the magnetic properties of the investigated complex with the geometry, which is presented in scheme 1 , the spin Hamiltonian (equation 1) model was used [4, 5].

$$
\hat{H}_{\text {total }}=\hat{H}_{z}+\hat{H}_{H D v V},
$$

where the isotropic (Heisenberg) exchange coupling term is described by

$$
\hat{H}_{H D V V}=-2 J_{w b}\left(\hat{S}_{1} \hat{S}_{2}+\hat{S}_{2} \hat{S}_{3}+\hat{S}_{3} \hat{S}_{4}+\hat{S}_{4} \hat{S}_{1}\right)-2 J_{b b} \hat{S}_{2} \hat{S}_{4}
$$

and Zeeman interaction of the Fe(III) spins with the applied magnetic field B, assumed in the $\mathrm{z}$ direction, is given by

$$
\hat{H}_{z:}=g \mu_{B}\left(\hat{S}_{1 z}+\hat{S}_{2 z}+\hat{S}_{3 z}+\hat{S}_{4 z}\right)
$$

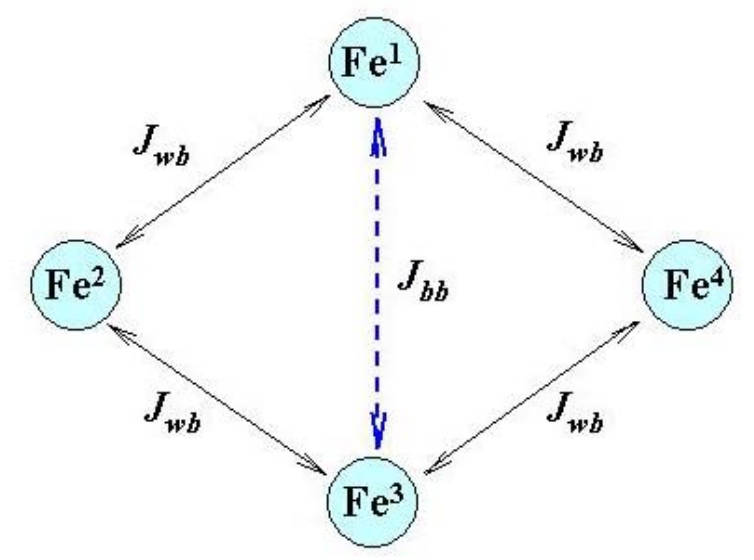

Scheme 1.

where $\widehat{S}_{i}$ is the spin operator on the $\mathrm{i}_{\mathrm{th}} \mathrm{Fe}(\mathrm{III})$ ion; $J$ is the exchange integral couplings Fe(III) ions; (The sign of $J$ is positive for parallel and negative for antiparallel spin coupling); $\mathrm{g}$ is the electronic gyromagnetic ratio; $\mu_{B}$ is the Bohr magneton and B - magnetic field strength.

The original least-squares fitting computer program FDHM [34] with a Full Diagonalisation of Hamiltonian Matrix approach was employed to fit $(\chi T)_{\exp }$ vs. T, in order to obtain the exchange couplings constants. By use of the spin product basis set of spin wave functions $\psi=\mid m_{S_{1}} m_{S_{2}} m_{S_{3}} m_{S_{4}}>$ a total of $1296\left(=\prod_{i=1}^{4}\left(2 S_{i}+1\right)\right)$ spin wave functions are obtained. The action of the spin Hamiltonian (1) on these wave function yields energy levels distributed with coupled spin quantum numbers, $0 \leq \mathrm{S}_{\mathrm{t}} \leq 10$.

The energy levels were determined by diagonalising the matrix

$$
H_{i j}\left(H_{i j}=<\psi_{i}\left|\hat{H}_{\text {total }}\right| \psi_{j}>\right)
$$

The diagonalisation was simplified by block-factoring the matrix into $M_{S_{t}}\left(=\sum_{i=1}^{4} m_{S_{i}}\right)$ submatrices, with the corresponding dimensions $1,4,10,20,35,56,80,104,125,140,146$.

The magnetic susceptibilities of the compound were calculated from the spin-coupled wave function by using a simplified form of the Van Vleck equation [2] 


$$
\begin{gathered}
\chi_{\text {mol }}=\frac{N_{A}}{k T} \frac{\sum_{i=1, n}\left|<\psi_{i}\right| \not \mu\left|\psi_{i}>\right|^{2} \exp \left(-E_{i} / k T\right)}{\sum_{i=1, n} \exp \left(-E_{i} / k T\right)} \\
\chi_{\text {mol }}=(1-\rho) \frac{N_{A}}{k T} \frac{\sum_{i=1, n}\left|<\psi_{i}\right| \not \mu\left|\psi_{i}>\right|^{2} \exp \left(-E_{i} / k T\right)}{\sum_{i=1, n} \exp \left(-E_{i} / k T\right)}+ \\
\rho \frac{1}{3} \frac{N_{A} \mu_{B}{ }^{2}}{k} \bar{g}^{2} \frac{S_{F e(I I I)}\left(S_{\text {Fe(III) }}+1\right)}{1-\frac{\theta_{\text {Curie_Weis }}}{T}}
\end{gathered}
$$

where $E_{i}$ is the energy level with wave function $\psi_{i}$ and $\hat{\mu}$ is the moment operator given by $\hat{\mu}=g \mu_{B} \sum_{i=1,4} \hat{S}_{z_{i}}$. vs. T.

The results of a least-squares fit of the magnetic data are illustrated in Fig. 2 as plots of the $(\chi \mathrm{T})_{\text {obs. }}$ and $(\chi \mathrm{T})_{\text {calc. }}$

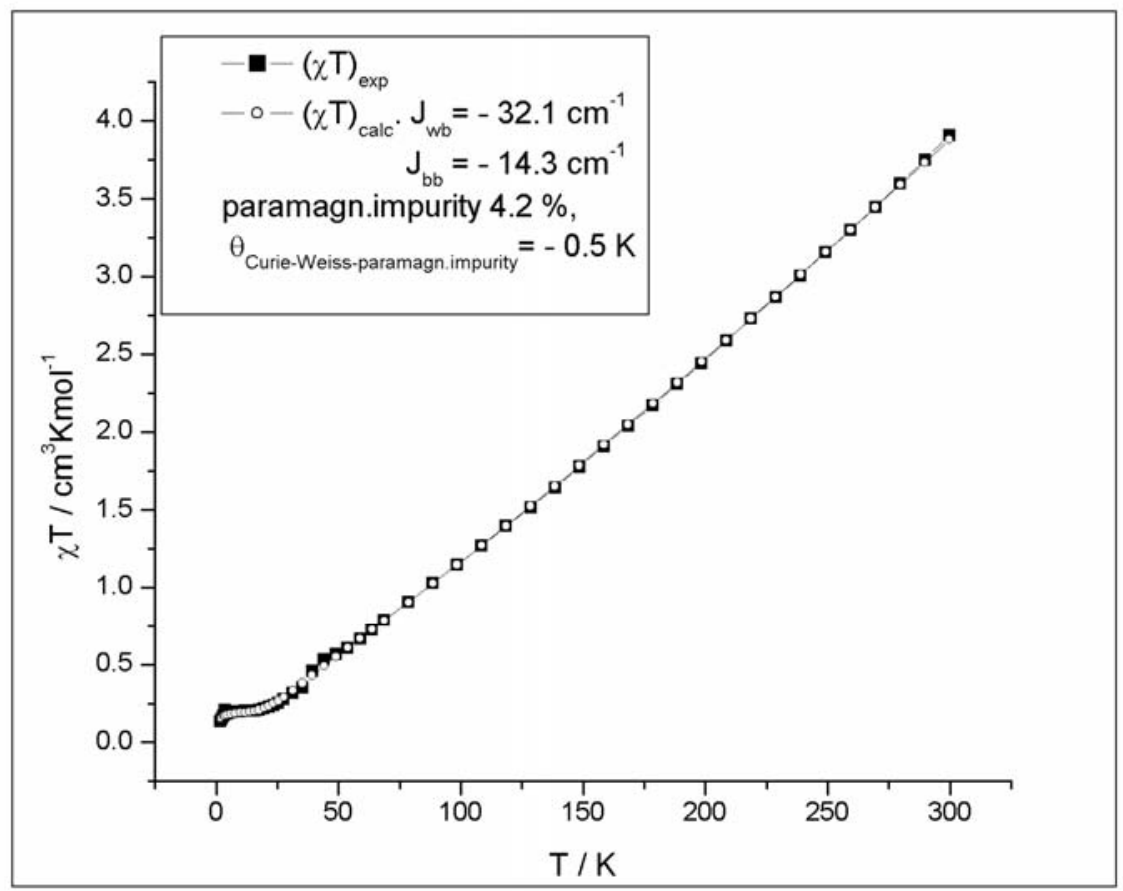

Figure 2. Temperature dependence of the magnetic susceptibility ( $\chi \mathrm{T}$ vs. T) of the 1 and best fit curve obtained with parameters reported in the text.

The calculated curve drawn through the experimental points represents the best fit of the model using the fitted parameters: $J_{w b}=-32.1 \mathrm{~cm}^{-1}, J_{b b}=-14.3 \mathrm{~cm}^{-1}, \bar{g}=2.07, \rho_{\text {par. imp. }}=4.2 \%, \Theta_{\text {Curie-Weiss const. }}=-0.5 \mathrm{~K}, R=6.8 \cdot 10^{-5}$, where $\left.R \equiv \sum\left[(\chi T)_{o b s .}-(\chi T)_{\text {calc. }}\right]^{2} / \sum(\chi T)^{2}{ }_{o b s}\right)$

- the reliability factor.

From the acquired data it is obvious that the absolute value of magnetic exchange parameter is very close to literature data $[20,22-26]$.

\section{Conclusion}

The novel bis $\left(\mu_{3}\right.$-oxo) tetranuclear trichloracetate cluster, $\left[\mathrm{Fe}_{4} \mathrm{O}_{2}\left(\mathrm{CCl}_{3} \mathrm{COO}\right)_{8}(\mathrm{THF})_{2}(\mathrm{DMF})\left(\mathrm{H}_{2} \mathrm{O}\right)\right] \cdot \mathrm{THF}(\mathbf{1})$, has been synthesised and subsequently characterised by $\mathrm{X}$-ray structure analysis, magnetic measurements and infra red (IR). The structure of cluster is "butterfly" type and is typical for such class of clusters. Magnetic studies reveal the presence of an antiferromagnetic exchange in the parallelogram skeletons of the tetranuclear species with next fitting parameters: $J_{b b}=-14.3 \mathrm{~cm}^{-1}, J_{w b}=-32.1 \mathrm{~cm}^{-1}, \mathrm{~g}=2.07, \rho_{\text {param. impur. }}=4.2 \%, \Theta_{\text {Curie-Weiss const. }}=-0.5 \mathrm{~K}$ and $\mathrm{R}=6.8 \cdot 10^{-5}$. It is necessary to mention that the antiferomagnetic interaction between Fe1 and F3 is unexpected but according [35] the 
value and sign of this parameter doesn't have any importance in fitting process of experimental and theoretical data. This fact needs the new conception in interpretation.

\section{Experimental}

General: The carbon and hydrogen content of complex was determined by standard micro-methods in the group of microanalysis of the Institute of Chemistry of the Academy of Sciences of Moldova.

IR spectrum of polycrystalline sample was recorded as vaseline mulls on a Specord M-75 spectrophotometer.

Synthesis of $\left[\mathrm{Fe}_{4} \mathrm{O}_{2}\left(\mathrm{CCl}_{3} \mathrm{COO}\right)_{8}(\mathrm{THF})_{2}(\mathrm{DMF})\left(\mathrm{H}_{2} \mathrm{O}\right)\right] \cdot \mathrm{THF}$ (1). The red tetrahydrofuran solution (THF, $\left.20 \mathrm{~mL}\right)$ of $\left[\mathrm{Fe}_{2} \mathrm{BaO}\left(\mathrm{CCl}_{3} \mathrm{COO}\right)_{6}(\mathrm{THF})_{6}\right] \cdot 0,5 \mathrm{H}_{2} \mathrm{O} \cdot 0,5 \mathrm{THF} \quad(2.15 \mathrm{~g}, 1.286 \mathrm{mmol})$ [36] and aqueous solution (20 mL) of $\mathrm{La}_{2}\left(\mathrm{SO}_{4}\right)_{3} \cdot 9 \mathrm{H}_{2} \mathrm{O}(0.62 \mathrm{~g}, 0.849 \mathrm{mmol})$ were added to toluene $(40 \mathrm{~mL})$ and the mixture stirred for $2 \mathrm{~h}$ after which "toluene-THF" orange layer was carefully removed out and kept at room temperature until all solvent was evaporated. The obtained orange powder was re-dissolved in DMF/THF/heptane (1:9:2) mixture (12 mL). After three days light orange single crystals of 1 grew that were suitable for X-ray analysis. Yield: $0.17 \mathrm{~g}(14 \%$ based on Fe). Elemental analysis (\%): Found: $\mathrm{C}, 20.86 ; \mathrm{H}, 1.75 ; \mathrm{Fe}, 12.12 \%$. Calcd. for $\left(\mathrm{C}_{31} \mathrm{H}_{33} \mathrm{Cl}_{24} \mathrm{NO}_{23} \mathrm{Fe}_{4}\right)$ : C, 20,00; H, 1.78; $\mathrm{Fe}, 12.00$.

IR data show (vaseline mulls, $\mathrm{cm}^{-1}$ ): $3650 \mathrm{~m}, 3470 \mathrm{mb}, 1700 \mathrm{~m}, 1673 \mathrm{msh}, 1645 \mathrm{~s} ; 1593 \mathrm{~s} ; 1590 \mathrm{~m} ; 1380 \mathrm{~s}, 1340 \mathrm{~s} ; 1010 \mathrm{w}$; 940w; $748 \mathrm{sh} ; 720 \mathrm{~m} ; 675 \mathrm{~m} ; 670 \mathrm{~s} ; 469 \mathrm{~m} ; 440 \mathrm{~m}$.

Magnetic measurements. Variable temperature susceptibility of 1 was measured with an Oxford Instruments Vibrating Sample Magnetometer (VSM) working between 0 and $12 \mathrm{~T}$ and in the $1.8-300.0 \mathrm{~K}$ temperature range. The diamagnetic Pascal's constants were used to correct the magnetic values [4, 5].

Crystallographic data. X-ray diffraction experimental data for 1 were collected at $100 \mathrm{~K}$ on a Kuma KM4CCD diffractometer (monochromated $\mathrm{MoK}_{\alpha}$ radiation). The crystal was positioned at the distance of $70 \mathrm{~mm}$ from the CCD chamber. Reflections of 142 frames in one set were collected with $\omega$ angle between the frames $0.5^{\circ}$. Intensity data were corrected for the Lorentz and polarization effects. The structure was solved by direct methods [37] and refined by fullmatrix least-squares on $F^{2}$ with anisotropic displacement parameters for non-H atoms [38]. The $\mathrm{CH}_{2}$ hydrogen atoms of THF moieties were located on $\Delta F$ map and their distances to $\mathrm{C}$ atoms have been standardized to $0.96 \AA$ with the isotropic displacement parameters fixed at $1.2 \times \mathrm{U}_{\text {eq }}$ of the relevant carbon atom. Positional parameters of $\mathrm{H}$-atoms of coordinated water molecules were verified by the geometric parameters of the corresponding hydrogen bonds. The structural parameters together with details of data collection and refinement for $\mathbf{1}$ are given in Table 2, while selected bond lengths and angles - in Table 1.

Table 2. Summary of Crystal Data and refinement details for $\left[\mathrm{Fe}_{4} \mathrm{O}_{2}\left(\mathrm{CCl}_{3} \mathrm{COO}\right)_{8}(\mathrm{THF})_{2}(\mathrm{DMF})\left(\mathrm{H}_{2} \mathrm{O}\right)\right] \mathrm{THF}(1)$.

\begin{tabular}{|c|c|}
\hline Empirical formula & $\mathrm{C}_{31} \mathrm{H}_{33} \mathrm{Cl}_{24} \mathrm{Fe}_{4} \mathrm{NO}_{23}$ \\
\hline$M$ & 1861.78 \\
\hline Wavelength, $\AA$ & 0.71073 \\
\hline $\begin{array}{c}\text { Crystal system, Space } \\
\text { group }\end{array}$ & Monoclinic, $\mathrm{P} 22_{1} / \mathrm{n}$ \\
\hline$a, \AA$ & $14.215(3)$ \\
\hline$b, \AA$ & $37.018(7)$ \\
\hline$c, \AA$ & $14.341(3)$ \\
\hline$\beta, \operatorname{deg}$ & $109.11(3)$ \\
\hline $\mathrm{V}, \AA^{3}$ & $7131(3)$ \\
\hline $\mathrm{Z}$ & 4 \\
\hline$\rho_{\text {(calcd.) }}, \mathrm{Mg} / \mathrm{m}^{3}$ & 1.734 \\
\hline$\mu_{\mathrm{Mo}}, \mathrm{mm}^{-1}$ & 1.760 \\
\hline Crystal size, $\mathrm{mm}$ & $0.3 \times 0.25 \times 0.20$ \\
\hline$\theta$ range, deg & 3.43 to 23.26 \\
\hline \multicolumn{2}{|l|}{ Number of reflections: } \\
\hline Measured & 7374 \\
\hline Unique & $5296\left[\mathrm{R}_{\mathrm{int}}=0.1012\right]$ \\
\hline $\begin{array}{l}\text { Number of refined } \\
\text { parameters }\end{array}$ & 258 \\
\hline GOOF for $F^{2}$ & 1.042 \\
\hline${ }^{a} R$ & 0.1402 \\
\hline${ }^{b} w R$ & 0.3865 \\
\hline$\Delta \rho_{\max }$ and $\Delta \rho_{\min }, \mathrm{e} \AA^{3}$ & 1.035 and -0.923 \\
\hline
\end{tabular}




\section{Acknowledgements}

The research described in this publication was made possible in part by Award No. BGPIII \#MOP-2-3061-CS-03 of the Moldovan Research and Development Association (MRDA) - U. S. Civilian Research \& Development Foundation (CRDF), and the INTAS project $n^{\circ} 00-00565$. V. Mereacre thanks also the AvH foundation.

\section{References}

[1] Welo, L. A. Philosoph. Magazine and journale of scienc. 1928, Vol.28, 36, 481-510.

[2] Van Vleck, J. H. Theory of Electric and Magnetic Susceptibilities. London, Oxford University Press, 1932.

[3] Tsukerblat, B. S.; Belinsky, M. I. Magnetochemistry and radiospectroscopy of exchange clusters, Shtiintsa, Kishinev, Moldova, 1983, 280 p. (rus).

[4] Kalinnikov, V.T.; Rakitin Yu.V. Introduction to magnethochemistry. The static magnetic susceptibility method in chemistry. Issue "Nauka" Moscow, 1980, 301 p. (rus).

[5] Kahn, O. Molecular magnetism. VCH Publishers Inc. New York, Weinheim, Cambridge, 1993, 380 p.

[6] Mehrota, R. C.; Bohra, R. Metal Carboxylates, Academic Press, London, 1983, 395.

[7] Clodfelder, B. J.; Upchurch, R. G.; Vincent, J. B. J. Inorg. Biochem. 2004, 98, 522-533.

[8] (a) Sessoli, R.; Tsai, H.-L.; Schake, A. R.; Wang, S.; Vincent, J.V.; Folting, K.; Gatteschi, D.; Christou, G. and Hendrickson, D. J. Am. Chem. Soc. 1993, 115, 1804-1816; (b) Gatteschi, D.; Sessoli, R. Angew. Chem. Int. Ed. 2003, 42, 268-297.

[9] Gatteschi, D.; Sessoli, R. and Cornia, A. J. Chem. Soc. Chem. Commun. 2000, 725-732.

[10] Miyasaka, H.; Clerac, R.; Wernsdorfer, W.; Lecren, L.; Bonhomme, C.; Sugiura, K. and Yamashita, M. Angew. Chem. Int. Ed. 2004, 43, 2801-2805.

[11] Que, L. Jr.; True, A. E. Progress in inorganic chemistry. 1990, 38, 97-200.

[12] Vincent, J. B.; Olivier-Lilley, G. L.; Averill, B. A. Chem. Rev. 1990, 90, 1447-1467.

[13] Doi, K.; Antanaitis, B.; Aisen, P. Struct.Bond. 1988, 70, 1-26.

[14] Klabunde, T.; Krebs, B. Struct. Bond 1997, 177-198.

[15] Dorsett, L. C.; Hawkins, C. J.; Grice, J. A.; Lavin, M. F.; Merefield, P. M.; Parry, D. L.; Ross, I. L. Biochemistry 1987, 26, 8078-8082.

[16] Taylor, S. W.; Cashion, J. D.; Brown, L. J.; Hawkins, C. J.; Hanson, G. R. Inorg. Chem. 1995, 34, $1487-1494$.

[17] Theil, E. C. Adv. Inorg. Biochem. 1983, 5, 1-38.

[18] Lippard, S. J. Angew.Chem. 1988, 100, 353-371.

[19] Ponomarev, V. I.; Atovmian, L.O.; Bobcova, S. A.; Turta, K. I. Proceed. Acad. Sciences of USSR 1984, T.274, 2, 368-373(rus).

[20] Turta, K. I.; Bobcova, S. A.; Kuyavskaia, B. Ya.; Ivleva, I. N.; Ponomarev, V. I.; Vekselman, M. E. Rus. Coord. Chem. 1985, Vol.11, nr.8, 1106-1112.

[21] Stulan, R.A.; Ponomarev, V. I.; Nifontov, V.I.; Turta, K. I.; Atovmian, L.O. J. Struct. Chem. 1985, Vol.26, 2, 6266(rus).

[22] Gorun, S. M.; Lippard, S. J. Inorg. Chem. 1988, 27, 149-156.

[23] Horn, A.; Neves, A.; Bortoluzzi, A. J.; Drago, V.; Ortiz, W. A. Inorg. Chem. Commun. 2001, 4, 173-176.

[24] Boudalis, A. K.; Lalioti, N.; Spyroulias, G. A.; Raptopoulou, C. P.; Terzis, A.; Tangoulis, V.; Perlepes, S. P. J. Chem. Soc. Dalton Trans. 2001, 955-957.

[25] Bing, Y.; Zhi-Da, Ch. Inorg. Chem. Commun. 2001, 4, 138-141.

[26] Wemple, M. W.; Coggin, D. K.; Vincent, J. B.; McClusker, J. K.; Streib, W. E.; Huffman, J. C.; Hendrickson, D. N. and Christou G. J. Chem. Soc. Dalton Trans. 1998, 719-725.

[27] Cui, Y.; Chen, J.-T.; Huang, J.-Sh., et al. Inorg. Chim. Acta 1999, 293(2), 129-139;

[28] Soler, M.; Chandra, S. K.; Ruiz, D.; Davidson, E. R.; Hendrickson, D. N. and Christou, G. Chem. Commun. 2000, 2417-2418.

[29] Soler, M.; Artus, P.; Folting, K.; Huffman, J. C.; Hendrickson, D. N. and Christou, G. Inorg. Chem. 2001, 49024912.

[30] Ng, S. W. Acta Cryst. 2004, E60(6), 738-740.

[31] Turta, C.; Shova, S.; Prodius, D.; Mereacre, V.; Gdaniec, M.; Simonov, Yu.; Lipkowski, J. Inorg. Chim. Acta 2004, 357, 4396-4404.

[32] Cannon, R. D.; White, R. P. Prog. Inorg. Chem. 1988, 36, 195-298.

[33] Faniran, J. A.; Patel, K. S. and Mesubi, M. A. Spectrochimica Acta 1975, 31A, 117-122.

[34] Stanica, N. Ph.D. Thesis, Romanian Academy, Institute of Physical Chemistry, 1997.

[35] James K. McCusker, John B. Vincent, Edward A. Schmitt, Marion L. Mino, Koo Shin, DeAnna K. Coggin, Paula M. Hagen, John C. Huffman, George Christou, and David N. Hendrickson. J. Am. Chem. SOC. 1991, 113, 3012-3021.

[36] Prodius, D.; Turta, C.; Mereacre, V.; Shova, S.; Gdaniec, M.; Simonov, Yu.; Lipkowski, J.; Kuncser, V.; Filoti, G. and Caneschi, A. Polyhedron 2006 (in press, 8 p.).

[37] Sheldrick, G. M. Acta Crystallogr. Sect. A: Found. Crystall. 1990, 46A, 6, 467-473.

[38] Sheldrick, G. M. SHELXL-97, University of Göttingen: Göttingen, Germany. 